\title{
CD8 Co-Receptor Staining Method
}

National Cancer Institute

\section{Source}

National Cancer Institute. CD8 Co-Receptor Staining Method. NCI Thesaurus. Code

C122850.

An immunohistochemical technique used to detect the presence of the heterodimeric T-

cell surface glycoprotein CD8 co-receptor protein complex in a tissue sample. 